\title{
The Zymomonas mobilis regulator $h f q$ contributes to tolerance against multiple lignocellulosic pretreatment inhibitors
}

\author{
Shihui Yang 1,2, Dale A Pelletier ${ }^{1}$, Tse-Yuan S Lu¹ and Steven D Brown*1,2
}

\begin{abstract}
Background: Zymomonas mobilis produces near theoretical yields of ethanol and recombinant strains are candidate industrial microorganisms. To date, few studies have examined its responses to various stresses at the gene level. Hfq is a conserved bacterial member of the Sm-like family of RNA-binding proteins, coordinating a broad array of responses including multiple stress responses. In a previous study, we observed Z. mobilis ZM4 gene ZMO0347 showed higher expression under anaerobic, stationary phase compared to that of aerobic, stationary conditions.

Results: We generated a Z. mobilis hfa insertion mutant AcRIM0347 in an acetate tolerant strain (AcR) background and investigated its role in model lignocellulosic pretreatment inhibitors including acetate, vanillin, furfural and hydroxymethylfurfural (HMF). Saccharomyces cerevisiae Lsm protein (Hfq homologue) mutants and Lsm protein overexpression strains were also assayed for their inhibitor phenotypes. Our results indicated that all the pretreatment inhibitors tested in this study had a detrimental effect on both Z. mobilis and S. cerevisiae, and vanillin had the most inhibitory effect followed by furfural and then HMF for both Z. mobilis and S. cerevisiae. AcRIM0347 was more sensitive than the parental strain to the inhibitors and had an increased lag phase duration and/or slower growth depending upon the conditions. The $h f q$ mutation in AcRIM0347 was complemented partially by trans-acting hfq gene expression. We also assayed growth phenotypes for S. cerevisiae Lsm protein mutant and overexpression phenotypes. Lsm 1, 6, and 7 mutants showed reduced tolerance to acetate and other pretreatment inhibitors. S. cerevisiae Lsm protein overexpression strains showed increased acetate and HMF resistance as compared to the wild-type, while the overexpression strains showed greater inhibition under vanillin stress conditions.

Conclusions: We have shown the utility of the pKNOCK suicide plasmid for mutant construction in Z. mobilis, and constructed a Gateway compatible expression plasmid for use in Z. mobilis for the first time. We have also used genetics to show Z. mobilis Hfq and S. cerevisiae Lsm proteins play important roles in resisting multiple, important industrially relevant inhibitors. The conserved nature of this global regulator offers the potential to apply insights from these fundamental studies for further industrial strain development.
\end{abstract}

\section{Background}

Biomass-based bioenergy is crucial to meet national goals of making cellulosic ethanol cost-competitive with gasoline. A core challenge in fermenting cellulosic material to ethanol is the recalcitrance of biomass to breakdown. Severe biomass pretreatments are therefore required to release the sugars, which along with by-products of fermentation can create inhibitors including sugar degrada-

* Correspondence: brownsd@ornl.gov

1 Biosciences Division, Oak Ridge National Laboratory, Oak Ridge, TN, 37831, USA

Full list of author information is available at the end of the article tion products such as furfural and hydroxymethylfurfural (HMF); weak acids such as acetic, formic, and levulinic acids; lignin degradation products such as the substituted phenolics vanillin and lignin monomers [1]. In addition, the metabolic byproducts such as ethanol, lactate, and acetate also influence the fermentation by slowing and potentially stopping the fermentation prematurely. The increased lag phase and slower growth increases the ethanol cost due to both ethanol production rate and total ethanol yield decreases $[2,3]$. One approach to overcome the issue of inhibition caused by pretreatment processes is to remove the inhibitor after pretreatment from the 
biomass physically or chemically, which requires extra equipment and time leading to increased costs. A second approach utilizes inhibitor tolerant microorganisms for efficient fermentation of lignocellulosic material to ethanol and their utility is considered an industrial requirement [1].

Z. mobilis are Gram-negative facultative anaerobic bacteria with a number of desirable industrial characteristics, such as high-specific productivity and ethanol yield, unique anaerobic use of the Entner-Doudoroff pathway that results in low cell mass formation, high ethanol tolerance (12\%), $\mathrm{pH} 3.5-7.5$ range for ethanol production and has a generally regarded as safe (GRAS) status [4-9]. $Z$. mobilis strains have been engineered to ferment pentose sugars such as xylose, arabinose and other substrates with high yields, but a low tolerance to acetic acid and decreased ethanol tolerance have been reported in recombinant strains $[4,10-12]$. Z. mobilis mutant strains tolerant to a pretreatment inhibitor such as acetate have been generated by chemical mutagenesis with $N$-methyl $N^{\prime}$-nitro $N$-nitrosoguanidine and selection in continuous culture with a progressively increasing concentration of sodium acetate in the medium feed [13]. AcR is capable of efficient ethanol production in the presence of $20 \mathrm{~g} / \mathrm{L}$ NaAc, while the parent ZM4 is inhibited significantly above $12 \mathrm{~g} / \mathrm{L}$ NaAc under the same conditions [13].

We have investigated $Z$. mobilis ZM4 gene expression and metabolomic profiles during aerobic and anaerobic conditions and found that aerobic, stationary phase conditions produced a number of inhibitory secondary metabolites [14] and the expression of a putative $h f q$ gene ZMO0347 was greater in anaerobic stationary phase compared to that of aerobic conditions [14]. Hfq is a global regulator that acts as an RNA chaperone and is involved in coordinating regulatory responses to multiple stresses [15-18]. However, little is known about $Z$. mobilis Hfq.

The aim of this study was to investigate the role of a putative $h f q$ gene ZMO0347 on multiple pretreatment inhibitor tolerances. $Z$. mobilis genetic modification has been reported previously with the $s a c C$, $a d h B$, and $n d h$ targets for mutagenesis [19-21]. However, the existence of native plasmids $[22,23]$ and intrinsic antibiotic resistance impedes the use of many broad-host-range plasmids $[22,24,25]$. In this work, we identified appropriate antibiotics for Z. mobilis genetic studies, created an expression plasmid vector, and utilized the pKNOCK-Km suicide plasmid [26] to create an $h f q$ mutant in Z. mobilis acetate tolerant strain AcR. We demonstrate that the $Z$. mobilis $h f q$ is important for $Z$. mobilis tolerance to several classes of lignocellulosic pretreatment inhibitors.

$\mathrm{Hfq}$ is part of an ancient family of proteins termed Sm and Sm-like (Lsm) proteins that are conserved among bacteria, archaea, and eukaryotes such as yeast S. cerevi- siae [16,27]. Seven core yeast Sm proteins form a heteroheptameric ring with a small central hole and are essential [28]. Eight Lsm proteins (LSM1, LSM2, LSM3, LSM4, LSM5, LSM6, LSM7, and LSM8) in S. cerevisiae form two different heteroheptameric rings containing either Lsm1p or Lsm8p with common Lsm2p-7p components [28]. The complex containing Lsm2-8p localizes to the nucleus and is involved in nuclear RNA processing, and the complex containing Lsm1-7p contributes to cytoplasmic RNA processing $[28,29]$. In addition, LSM9 (MAK31) has also been reported to contain a Sm domain, as well as other proteins such as LSM12 (YHR121W), LSM13 (SCD6, YPR129W), and LSM16 (EDC3, YEL015W) [29]. In this study, we also show that S. cerevisiae Lsm1, 6, and 7 proteins contribute to yeast pretreatment inhibitor tolerance.

\section{Results}

Bioinformatics analysis of a putative Z . mobilis $\mathrm{Hfq}$ and related S. cerevisiae proteins

To assess whether Z. mobilis ZMO0347 was similar to other known members of the Hfq family of regulators, the ZMO0347 protein sequence was used in a BlastP analysis [30]. The BlastP result indicates that ZMO0347 is similar to the E. coli global regulator Hfq protein $(60 \%$ sequence identity), and to eukaryotic homologues such as Sm or Lsm proteins exist in other microorganisms like S. cerevisiae (Additional file 1). These analyses suggest that ZMO0347 is likely an Hfq regulator family protein in $Z$. mobilis. Interestingly, the Z. mobilis ZMO0347 (Hfq) protein possesses two Sm-like family domains, two intrahexamer interaction sites, two inter-hexamer interaction sites, two nucleotide binding pockets, and has an extra $\mathrm{Sm}$-like domain near the C-terminus (Additional file 1A) which is unlike most of the bacterial $\mathrm{Hfq}$ protein sequences that have only one $\mathrm{Sm}$-like domain (Additional file 1). S. cerevisiae has nineteen proteins with a $\mathrm{Sm}$ or Sm-like domain, and although examples like Sm protein (SmB) and Lsm protein (Lsm1) (Additional file 1C, D, respectively) contain $\mathrm{Sm}$-like domains, significant sequence similarity was not observed by BlastP analysis.

\section{Z. mobilis AcR strain hfq mutant construction and complementation}

Intrinsic Z. mobilis antibiotic resistance has been reported previously $[22,25]$, which restricts the use of the available broad-host-range plasmids. We tested the antibiotic sensitivities of ZM4 and AcR as an initial step for genetic studies with these strains. Each strain was tested against the following antibiotics; chloramphenicol (25, $50,100$, and $200 \mu \mathrm{g} / \mathrm{mL})$, gentamicin $(100,200$, and 300 $\mu \mathrm{g} / \mathrm{mL})$, kanamycin $(100,200$, and $300 \mu \mathrm{g} / \mathrm{mL})$, streptomycin $(200$ and $300 \mu \mathrm{g} / \mathrm{mL})$, and tetracycline $(25,50,100$, and $200 \mu \mathrm{g} / \mathrm{mL}$ ). Each assay was conducted under aerobic 
and anaerobic conditions and similar growth results were observed under the respective conditions for the different doses. Z. mobilis was tolerant to streptomycin at concentration of $300 \mu \mathrm{g} / \mathrm{mL}$ and gentamicin at $100 \mu \mathrm{g} / \mathrm{mL}$. $Z$. mobilis was able to grow slightly at $100 \mu \mathrm{g} / \mathrm{mL}$ kanamycin and $300 \mu \mathrm{g} / \mathrm{mL}$ gentamicin, and was sensitive to tetracycline and chloramphenicol at concentrations above 25 $\mu \mathrm{g} / \mathrm{mL}$ (data not shown).

We generated an $h f q$ insertion mutant in a Z. mobilis acetate tolerant strain (AcR) background using the pKnock-Km suicide plasmid system [26,31], and designated it as strain AcRIM0347 (See Methods for details). Since many mutagenesis systems use either chloramphenicol or kanamycin markers, tetracycline resistance was used as an expression plasmid antibiotic marker for new Gateway entry vector pBBR3DEST42 construction (Additional file 2), which was then used to generate plasmid p42-0347 to express $h f q$ gene ZMO0347. The nucleotide sequence for plasmid p42-0347 was verified by Sanger sequencing, and the expression of $h f q$ from plasmid p42-0347 in E. coli was confirmed by Western blot analysis (data not shown). Plasmid p42-0347 was then introduced into the wild-type strain ZM4, acetate tolerant mutant AcR, and $h f q$ mutant AcRIM0347 background by conjugation and selection. The presence of correct p42-0347 construct in ex-conjugants was confirmed by PCR and Sanger sequencing analysis. The oligonucleotide primers used to generate $h f q$ mutant AcRIM0347 and complement $h f q$ mutation in AcRIM0347 are listed in Table 1.

\section{Z. mobilis hfq contributes to pretreatment inhibitor tolerance}

Pretreatment inhibitors had negative effects on $Z$. mobilis growth: the growth of $Z$. mobilis strains was reduced in the presence of acetate, vanillin, furfural, or HMF with increased lag phases and/or slower growth rates and/or final bacterial cell densities depending on the respective condition and strain (Table 2, 3; Fig. 1, 2). Among the different forms of acetate counter-ions tested, sodium acetate had the most inhibitory effect on wildtype $Z$. mobilis growth. This was followed by potassium acetate and ammonium acetate and sodium chloride had the least negative influence on wild-type $Z$. mobilis growth (Table 2; Fig. 1). Wild-type ZM4 growth was completely inhibited when RM medium was amended with $195 \mathrm{mM}$ sodium acetate (Table 2; Fig. 1C) in keeping with previous reports [13]. Among the pretreatment inhibitors of vanillin, furfural, and HMF, vanillin had the most inhibitory effect on $Z$. mobilis and HMF the least (Table 3). Z. mobilis took longer to complete active growth and reach the stationary phase, which was about 16,19 or $21 \mathrm{~h}$ in the presence of HMF, furfural or vanillin, respectively, compared to $11 \mathrm{~h}$ without any inhibitor present in the medium (Fig. 2).

Hfq contributes to sodium and acetate ion tolerances: although the final cell density of hfq mutant AcRIM0347 is similar to that of AcR parental strain (Table 2; Fig. 2A), the growth rate of AcRIM0347 was reduced about onefifth even without any inhibitor in the RM, which indicates hfq plays a central role in normal Z. mobilis physiology. Wild-type ZM4 that contained p42-0347 was able to grow in the presence of $195 \mathrm{mM}$ sodium acetate and had a similar growth rate and final cell density to that of acetate tolerant strain AcR (Table 2; Fig. 1C). The wild-type ZM4 was unable to grow under this condition.

The inactivation of the $h f q$ gene in AcR decreased this acetate tolerant strain's resistance to both sodium ion (sodium chloride) and acetate ion (ammonium acetate and potassium acetate) (Table 2; Fig. 1). hfq mutant AcRIM0347 was unable to grow in the presence of 195 $\mathrm{mM}$ ammonium acetate or potassium acetate (Table 2; Fig. 1D, E). Both the growth rate and final cell density of $h f q$ mutant AcRIM0347 were reduced by at least a quarter in the presence of $195 \mathrm{mM}$ sodium chloride, and about $60 \%$ in the presence of $195 \mathrm{mM}$ sodium acetate compared to that of the parental strain AcR (Table 2; Fig. 1B, C). The AcRIM0347 $h f q$ mutation was complemented by the introduction of an $h f q$-expressing plasmid (p420347) into the strain. The complemented mutant strain recovered at least half of the parental strains growth rate and $70 \%$ of its final cell density in the presence of $195 \mathrm{mM}$ acetate ion (whether as sodium, ammonium or potassium acetate) (Table 2; Fig. 1).

Hfq contributes to vanillin, furfural and HMF tolerances: AcRIM0347 growth rates were lower than that of ZM4 and AcR under all conditions tests, and except for growth in RM broth (Table 3; Fig. 2). AcRIM0347 also achieved lower final cell densities compared to ZM4 and AcR (Table 3; Fig. 2). When AcRIM0347 was provided functional $Z$. mobilis $\mathrm{Hfq}$ via $\mathrm{p} 42-0347$, growth rates under all conditions were largely unchanged (Table 3). However, shorter lag phases were observed for AcRIM0347 (p42-0347) grown with vanillin, furfural or HMF and increases in final cell densities were also observed under these conditions (Table 3; Fig. 2). These data indicate that $h f q$ is important for optimal $Z$. mobilis growth and its ability to resist furfural, HMF and vanillin toxicity.

\section{Yeast Lsm proteins contribute to pretreatment inhibitor tolerance}

Lsm protein and yeast tolerance to sodium and acetate ions

S. cerevisiae Sm and Sm-like (Lsm) proteins are similar to $Z$. mobilis Hfq at the level of protein sequence (Additional file 1). Growth of yeast Lsm deletion mutants and 
Table 1: Bacterial strains, plasmids and primers used in this study

\begin{tabular}{|c|c|c|}
\hline Strain, plasmid, or primer & $\begin{array}{l}\text { Genotype, phenotype, or sequence of primer } \\
\left.\text { (5' to } 3^{\prime}\right)\end{array}$ & Reference \\
\hline \multicolumn{3}{|l|}{ E. coli } \\
\hline $\mathrm{K}-12$ & K-12 MG1655 Wild-type strain & \\
\hline $\mathrm{DH} 5 \mathrm{a}$ & $\begin{array}{l}\mathrm{F}-480 \mathrm{~d} / a c Z \Delta \mathrm{M} 15 \Delta(\text { lacZYA-argF) U169 recA1 } \\
\text { endA1 hsdR17 }\left(\mathrm{r}_{\mathrm{k}^{-}}, \mathrm{m}_{\mathrm{k}}^{+}\right) \text {phoA supE44 } \lambda^{-} \text {thi-1 } \\
\text { gyrA96 relA1 }\end{array}$ & Novagen \\
\hline DB3.1 & 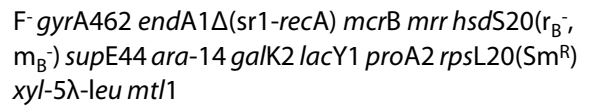 & Invitrogen \\
\hline WM3064 & $\begin{array}{l}\text { thrB1004 pro thi rpsL hsdS lacZAM15 RP4-1360 } \\
\Delta(\text { araBAD)567 } \triangle \text { dapA1341::[erm pir] }\end{array}$ & W. Metcalf \\
\hline BL21(DE3) & F- omp T hsdSB(rB-mB-) gal dcm (DE3) & Invitrogen \\
\hline \multicolumn{3}{|l|}{ Z. mobilis } \\
\hline ZM4 & ATCC31821 & ATCC \\
\hline$A c R$ & $\begin{array}{l}\text { ZM4 acetate tolerant strain generated by random } \\
\text { mutagenesis }\end{array}$ & [13] \\
\hline AcRIM0347 & $\begin{array}{l}\text { hfq:::pKm-0347, insertional mutant of AcR hfq } \\
\text { gene ZMO0347 }\end{array}$ & This study \\
\hline AcRIM0347 (p42-0347) & AcRIM0347 containing plasmid p42-0347 & This study \\
\hline ZM4(p42-0347) & ZM4 containing plasmid p42-0347 & This study \\
\hline AcR (p42-0347) & AcR containing plasmid p42-0347 & This study \\
\hline \multicolumn{3}{|l|}{ S. cerevisiae } \\
\hline BY4741 & $\begin{array}{l}\text { MATa his } 3 \Delta 1 \text { leu } 2 \Delta 0 \text { ura } 3 \Delta 0 \text { met } 15 \Delta 0 \text { - s } 288 \mathrm{c} \\
\text { background }\end{array}$ & Open Biosystems \\
\hline YSC1021-554440 & $\begin{array}{l}\text { Yeast: Yeast Knock Out Strain (YKO_LSM1) } \\
\text { Clone Id: 1301; Accession: YJL124C (Lsm1) }\end{array}$ & Open Biosystems \\
\hline YSC1021-552226 & $\begin{array}{l}\text { Yeast: Yeast Knock Out Strain (YKO_LSM6) } \\
\text { Clone Id: } 4214 \text {; Accession: YDR378C (Lsm6) }\end{array}$ & Open Biosystems \\
\hline YSC1021-556031 & $\begin{array}{l}\text { Yeast: Yeast Knock Out Strain (YKO_LSM7) } \\
\text { Clone Id: 7383; Accession: YNL147W (Lsm7) }\end{array}$ & Open Biosystems \\
\hline YSC1021-552677 & $\begin{array}{l}\text { Yeast: Yeast Knock Out Strain (YKO_LSM9) } \\
\text { Clone Id: 3501; Accession: YCR020C-A (Mak31P, } \\
\text { Lsm9) }\end{array}$ & Open Biosystems \\
\hline YSC1021-552563 & $\begin{array}{l}\text { Yeast: Yeast Knock Out Strain (YKO_LSM12) } \\
\text { Clone Id: 1949; Accession: YHR121W (Lsm12) }\end{array}$ & Open Biosystems \\
\hline YSC1021-553518 & $\begin{array}{l}\text { Yeast: Yeast Knock Out Strain (YKO_LSM13) } \\
\text { Clone Id: 5544; Accession: YPR129W (Lsm13) }\end{array}$ & Open Biosystems \\
\hline YSC1021-552280 & $\begin{array}{l}\text { Yeast: Yeast Knock Out Strain (YKO_LSM16) } \\
\text { Clone Id: } 255 \text {; Accession: YEL015W (Lsm16) }\end{array}$ & Open Biosystems \\
\hline YSC4515-98807049 & $\begin{array}{l}\text { Yeast GST-Tagged Strain (GST_LSM1) } \\
\text { Clone Id:YJL124C; Accession: YJL124C (Ism1) }\end{array}$ & Open Biosystems \\
\hline YSC4515-98811389 & $\begin{array}{l}\text { Yeast GST-Tagged Strain (GST_LSM6) } \\
\text { Clone Id:YDR378C; Accession: YDR378C (Lsm6) }\end{array}$ & Open Biosystems \\
\hline YSC4515-98805426 & $\begin{array}{l}\text { Yeast GST-Tagged Strain (GST_LSM9) } \\
\text { Clone Id: YCR020C-A; Accession: YCR020C-A } \\
\text { (Mak31P, Lsm9) }\end{array}$ & Open Biosystems \\
\hline YSC4515-98806813 & $\begin{array}{l}\text { Yeast GST-Tagged Strain (GST_LSM12) } \\
\text { Clone Id: YHR121W; Accession: YHR121W (Lsm12) }\end{array}$ & Open Biosystems \\
\hline
\end{tabular}


Table 1: Bacterial strains, plasmids and primers used in this study (Continued)

\begin{tabular}{|c|c|c|}
\hline YSC4515-98808930 & $\begin{array}{l}\text { Yeast GST-Tagged Strain (GST_LSM13) } \\
\text { Clone Id: YPR129W; Accession: YPR129W (Lsm13) }\end{array}$ & Open Biosystems \\
\hline YSC4515-98809076 & $\begin{array}{l}\text { Yeast GST-Tagged Strain (GST_LSM16) } \\
\text { Clone Id: YEL015W; Accession: YEL015W (Lsm16) }\end{array}$ & Open Biosystems \\
\hline \multicolumn{3}{|l|}{ Plasmids } \\
\hline pKNOCK-Km & $\begin{array}{l}\mathrm{Km}^{\mathrm{r}}, \text { mob, broad host range suicide cloning } \\
\text { vector, } 1.8 \mathrm{~kb}\end{array}$ & {$[26]$} \\
\hline pET-DEST42 & $\mathrm{Ap}^{r}, \mathrm{Cm}^{r}, \mathrm{C}$-terminal $6 \times \mathrm{His}$ and V5 epitope & Invitrogen \\
\hline pDONR221 & $\mathrm{Km}^{\mathrm{r}}$, gateway entry vector $\mathrm{Gm}^{\mathrm{r}}$, N-terminal GST & Invitrogen \\
\hline pBBR1MCS-3 & $\mathrm{T}^{\mathrm{r}}$, mob, broad host range cloning vector & [36] \\
\hline pBBR3DEST42 & $\mathrm{Cm}^{r} \mathrm{Tc}^{r}, \mathrm{C}$-terminal $6 \times \mathrm{His}$ and V5 epitope & This study \\
\hline pKm-0347 & $\begin{array}{l}\text { pKnock-Km containing 262-bp hfq internal } \\
\text { fragment for insertional mutant construction }\end{array}$ & This study \\
\hline p42-0347 & pBBR3DEST42 containing ZM4 gene ZMO0347 & This study \\
\hline \multicolumn{3}{|l|}{ PCR Primers } \\
\hline hfq_MF & cggagagatggtcagtcaca & 262-bp \\
\hline hfq_MR & ttcttgctgctgcataatcg & \\
\hline hfq_CF & $\begin{array}{l}\text { ggggacaagtttgtacaaaaaagcaggcttcgaaggagatag } \\
\text { aATGGCCGAAAAGGTCAACAATC }\end{array}$ & 483-bp \\
\hline hfq_CR & $\begin{array}{l}\text { ggggaccactttgtacaagaaagctgggtcATCCTCGTCTC } \\
\text { GGCTTTCTG }\end{array}$ & \\
\hline hfq_OCF & Caaagcttgagctcgaattcatttttgccgtggtagttgc & 1050-bp \\
\hline hfq_OCR & caggtacctctagaattcaccactcaatcctcgtctcg & \\
\hline
\end{tabular}

hfq_MF and hfq_MR are primers used for insertional mutant construction using pKnock mutagenesis system. Hfq_OCF and Hfq_OCR are primers for mutant confirmation. Hfq_CF and Hfq_CR are primers used to clone the $h f q$ gene into low copy number Gate-Way compatible plasmid pBBR3DEST42 for complementation, which results in a plasmid called p42-0347.

Lsm over-expressing strains in $305 \mathrm{mM}$ ammonium acetate, potassium acetate, or sodium acetate was assessed to test whether S. cerevisiae Lsm proteins and ZM4 Hfq had functionally similar roles. These studies included seven Lsm deletion mutants affecting three Lsm heteroheptameric ring components (Lsm1, Lsm6, Lsm7) and four other Lsm proteins containing an Sm domain (Lsm9, Lsm12, Lsm13, Lsm16), as well as six Lsm protein over-expressing strains (Lsm1, Lsm6, Lsm9, Lsm12, Lsm13, Lsm16). We present growth data for those genes that gave clear phenotypic differences for the sake of clarity and a list of all strains tested in this study can be found in Table 1.

Growth differences between the Lsm mutants and yeast wild-type BY4741 in the CM broth without the addition of acetate or with $305 \mathrm{mM} \mathrm{NaCl}$ were not observed (Additional file 3A, B, respectively). S. cerevisiae Lsm proteins involved in RNA processing ring complex formation (Lsm1, 6, 7), especially Lsm6, played a role in acetate tolerance (Additional file 3C-E, K-M). Lsm protein deletion mutants Lsm1, 6, and 7 showed decreased acetate tolerance compared to the wild-type control strain, especially in early growth stages for acetate with sodium, ammonium and potassium counter-ions (Additional file 3C-E). The Lsm overexpression strains grew similarly to wild-type BY4741 without the addition of acetate or with $305 \mathrm{mM} \mathrm{NaCl}$ (Additional file 3I, J), but each of the Lsm protein overexpression strains showed enhanced acetate tolerance compared to the wild-type strain with sodium, ammonium or potassium counter-ions (Additional file 3K-M).

Lsm proteins and yeast tolerance to vanillin, furfural and $H M F$ the effect of Lsm proteins on S. cerevisiae tolerance to pretreatment inhibitors vanillin, furfural, and HMF was also investigated using the seven Lsm deletion mutants and six Lsm overexpression strains described above. Each yeast deletion mutant and each overexpression strain showed similar growth profiles compared to wild-type strain BY4741 in the absence of inhibitors (Additional file 
Table 2: Growth rate and final cell density of different $Z$. mobilis strains in the absence or presence of different sodium and acetate ions.

\begin{tabular}{|c|c|c|c|c|c|c|}
\hline & & ZM4 & AcR & AcRIM0347 & $\begin{array}{l}\text { AcRIM0347 } \\
\text { (p42-0347) }\end{array}$ & $\begin{array}{c}\text { ZM4 } \\
(\mathrm{p} 42-0347)\end{array}$ \\
\hline \multirow{5}{*}{$\begin{array}{l}\text { Growth rate } \\
\text { (hour-1) }\end{array}$} & $\mathbf{R M}$ & $0.42 \pm 0.01$ & $0.39 \pm 0.01$ & $0.32 \pm 0.003$ & $0.33 \pm 0.002$ & $0.38 \pm 0.003$ \\
\hline & RM ( $\mathrm{NaCl})$ & $0.24 \pm 0.008$ & $0.29 \pm 0.005$ & $0.21 \pm 0.008$ & $0.22 \pm 0.009$ & $0.25 \pm 0.008$ \\
\hline & RM (NH4OAC) & $0.20 \pm 0.008$ & $0.19 \pm 0.005$ & NA & $0.22 \pm 0.002$ & $0.19 \pm 0.007$ \\
\hline & RM (Kac) & $0.15 \pm 0.004$ & $0.12 \pm 0.000$ & NA & $0.09 \pm 0.003$ & $0.12 \pm 0.006$ \\
\hline & $\mathrm{RM}(\mathrm{NaAc})$ & NA & $0.29 \pm 0.04$ & $0.12 \pm 0.004$ & $0.16 \pm 0.002$ & $0.27 \pm 0.004$ \\
\hline \multirow{5}{*}{$\begin{array}{l}\text { Final Cell Density } \\
(\text { OD600 nm) }\end{array}$} & RM & $0.95 \pm 0.006$ & $1.01 \pm 0.006$ & $0.94 \pm 0.004$ & $0.92 \pm 0.002$ & $1.02 \pm 0.004$ \\
\hline & $\mathrm{RM}(\mathrm{NaCl})$ & $0.73 \pm 0.01$ & $0.96 \pm 0.01$ & $0.73 \pm 0.03$ & $0.72 \pm 0.02$ & $0.84 \pm 0.01$ \\
\hline & RM (NH4OAc) & $0.43 \pm 0.01$ & $0.42 \pm 0.006$ & NA & $0.32 \pm 0.007$ & $0.37 \pm 0.008$ \\
\hline & RM (Kac) & $0.42 \pm 0.002$ & $0.40 \pm 0.000$ & NA & $0.28 \pm 0.007$ & $0.34 \pm 0.004$ \\
\hline & $\mathrm{RM}(\mathrm{NaAc})$ & NA & $0.63 \pm 0.02$ & $0.25 \pm 0.001$ & $0.45 \pm 0.002$ & $0.59 \pm 0.002$ \\
\hline
\end{tabular}

"NA" indicates that the data are not available due to the lack of growth in that condition. The concentration for all the chemicals (NaCl, $\mathrm{NH}_{4} \mathrm{OAc}$, KAc, NaAc) supplemented into the $\mathrm{RM}$ is $195 \mathrm{mM}$. NaCl: sodium chloride, $\mathrm{NH}_{4} \mathrm{OAc}$ : ammonium acetate, KAc: potassium acetate, $\mathrm{NaAc}$ : sodium acetate. Strains included in this study are: ZM4: Zymomonas mobilis ZM4 wild-type; AcR: previously described ZM4 acetate tolerant mutant; ZM4 (p42-0347): ZM4 containing a gateway plasmid p42-0347 to express ZM4 gene ZMO0347; AcRIM0347: AcR insertional mutant of ZMO0347; AcRIM0347 (p42-0347): AcRIM0347 containing gateway plasmid p42-0347. This experiment has been repeated at least three times with similar result. Duplicate biological replicates were used for each condition.

3A; I). Deletion mutants for Lsm1, 6 and 7 proteins were unable to grow or showed extended lag phases before recovery from the inhibitory effects of pretreatment inhibitors (Additional file 3F-H). Overexpression of Lsm proteins provided a slight growth advantage in the presence of $1.5 \mathrm{~g} / \mathrm{L} \mathrm{HMF}$ and furfural (Additional file 3O-P). However, a detrimental effect on growth was observed for overexpression strains when cultured in the presence of $0.75 \mathrm{~g} / \mathrm{L}$ vanillin (Additional file $3 \mathrm{~N}$ ). The data indicated that Lsm proteins Lsm1, 6, and 7 especially Lsm6, which are the components of yeast RNA processing ring complex, play a role in tolerance to the model inhibitors used in this study.

\section{Discussion}

A previous study indicated that $Z$. mobilis ZM4 $h f q$ was less abundant in aerobic, stationary phase fermentations compared to the equivalent anaerobic condition and that $r p o H$ was induced under the aerobic condition [14]. The role of $Z$. mobilis regulators like $\mathrm{Hfq}$ and extent of cross talk between regulatory networks remains to be elucidated. This study indicated that $h f q$ also plays a role in $Z$. mobilis resistance to both acetate (sodium acetate, potassium acetate, or ammonium acetate) and sodium ions (sodium chloride and sodium acetate) (Table 2; Fig. 1). A recent study has identified that nhaA overexpression (encoding a sodium-proton antiporter) conferred the previously reported AcR (sodium acetate tolerant) mutant phenotype [32]. Constitutive nhaA over-expression in strain AcRIM0347 ( $\left.h f q^{-}\right)$is a likely possibility for it being unable to survive with $195 \mathrm{mM}$ ammonium acetate or potassium acetate, while the same concentration of sodium acetate only partially repressed its growth. $h f q$ or nhaA each contribute to sodium acetate tolerance (Table 2; Fig. 1C) [32], but there is no additive benefit for increased inhibitor tolerance for $h f q$ and $n h a A$ if both were over-expressed at the same time (data not shown). In addition, the overexpression of nhaA gene in $Z$. mobilis had no advantage over other physiological stress responses for model pretreatment inhibitors such as vanillin, furfural, and HMF [32]. While Z. mobilis hfq contributes to the tolerance of these inhibitors as shown by increased $h f q$ mutant AcRIM0347 lag phases and slower growth rates during early logarithmic growth phase compared to AcR strain (Fig. 2). These separate studies indicate there may often be more than one pathway for industrial strain development.

The majority of proteins similar to Z. mobilis Hfq contained one Sm-like superfamily domain (Additional file 3 ), with the exception of those from six other species also 
Table 3: Growth rate and final cell density of different $Z$. mobilis strains in the absence or presence of different pretreatment inhibitors.

\begin{tabular}{|c|c|c|c|c|c|}
\hline & & ZM4 & AcR & AcRIM0347 & $\begin{array}{l}\text { AcRIM0347(p42- } \\
\text { 0347) }\end{array}$ \\
\hline \multirow{4}{*}{$\begin{array}{l}\text { Growth rate } \\
\text { (hour-1) }\end{array}$} & $\mathbf{R M}$ & $0.48 \pm 0.03$ & $0.46 \pm 0.003$ & $0.35 \pm 0.004$ & $0.32 \pm 0.003$ \\
\hline & HMF & $0.36 \pm 0.02$ & $0.35 \pm 0.01$ & $0.19 \pm 0.02$ & $0.22 \pm 0.001$ \\
\hline & Furfural & $0.31 \pm 0.01$ & $0.30 \pm 0.005$ & $0.19 \pm 0.03$ & $0.20 \pm 0.01$ \\
\hline & Vanillin & $0.26 \pm 0.001$ & $0.26 \pm 0.01$ & $0.20 \pm 0.006$ & $0.20 \pm 0.003$ \\
\hline \multirow{4}{*}{$\begin{array}{l}\text { Final Cell Density } \\
(\text { OD600 nm) }\end{array}$} & RM & $0.91 \pm 0.01$ & $0.98 \pm 0.006$ & $0.95 \pm 0.003$ & $0.92 \pm 0.006$ \\
\hline & HMF & $0.93 \pm 0.003$ & $0.96 \pm 0.006$ & $0.67 \pm 0.03$ & $0.78 \pm 0.02$ \\
\hline & Furfural & $0.88 \pm 0.006$ & $0.89 \pm 0.009$ & $0.67 \pm 0.001$ & $0.80 \pm 0.02$ \\
\hline & Vanillin & $0.69 \pm 0.006$ & $0.71 \pm 0.01$ & $0.66 \pm 0.01$ & $0.70 \pm 0.01$ \\
\hline
\end{tabular}

The concentration for the inhibitor supplemented into the RM is: HMF: $0.75 \mathrm{~g} / \mathrm{L}$, furfural, or vanillin: $1 \mathrm{~g} / \mathrm{L}$. Strains included in this study are: ZM4: Zymomonas mobilis ZM4 wild-type; AcR: previously described ZM4 acetate tolerant mutant; AcRIM0347: AcR insertional mutant of ZMO0347; AcRIM0347 (p42-0347): AcRIM0347 containing gateway plasmid p42-0347. This experiment has been repeated at least three times with similar result. Duplicate biological replicates were used for each condition.

within the Sphingomonadales. Future structural studies are required to define the role for Z. mobilis and other microorganisms with two Sm-like family domains, to elucidate Hfq subunit interactions, and to test whether only three Hfq proteins would be needed for Z . mobilis to form the active homo-hexameric ring structure.

We assayed growth phenotypes for S. cerevisiae Lsm protein mutant and overexpression phenotypes. Lsm1, 6, and 7 mutants showed reduced tolerance to acetate and other pretreatment inhibitors (Additional file 3). The $S$. cerevisiae Lsm over-expression studies showed these strains had increased acetate and HMF resistance compared to the wild-type strain, while the overexpression strains were more inhibited under vanillin stress conditions (Additional file 3). The conserved nature of Sm-like proteins, the involvement of ZM4 Hfq and S. cerevisiae $\mathrm{Sm}$-like proteins in pretreatment inhibitor tolerance offers the possibility of manipulating $h f q$ and members of the Lsm family for strain development purposes.

\section{Conclusions}

We created a plasmid for gene expression and mutation complementation in Z. mobilis and used the pKnock system to create an $h f q$ mutant in $Z$. mobilis acetate tolerant strain AcR. We showed that Z. mobilis hfq played a role in tolerance to multiple biomass pretreatment inhibitors including acetate, vanillin, furfural, and HMF. In addition, Hfq homologues of yeast Lsm proteins Lsm1, 6, and 7 involving in the RNA processing heteroheptameric ring complex formation, especially Lsm6, contribute to multi- ple pretreatment inhibitor tolerance in S. cerevisiae. However, further studies such as systems biology studies and ChIP-Seq are required to elucidate the $h f q$ stress response regulon in $Z$. mobilis and the yeast inhibitor tolerance genes affected by the RNA processing Lsm complexes.

\section{Methods}

\section{Strains and culture conditions}

Bacterial strains and plasmids used in this study are listed in Table 1. E. coli strains were cultured using Luria-Bertani (LB) broth or agar plates. E. coli WM3064 was supplemented with $100 \mu \mathrm{g} / \mathrm{mL}$ diaminopimelic acid (DAP). Z. mobilis ZM4 was obtained from the American Type Culture Collection (ATCC 31821) and the Z. mobilis acetate tolerant strain AcR has been described previously [13]. ZM4 and AcR were cultured in RM medium (Glucose, 20.0 g/L; Yeast Extract, 10.0 g/L; KH2PO4, 2.0 g/L, pH5.0) at $30^{\circ} \mathrm{C}$.

S. cerevisiae wild-type, deletion mutant and GST-fusion ORF overexpression strains were obtained through Open Biosystems (Huntsville, AL). S. cerevisiae strains were cultured in CM medium with $2 \%$ glucose for wild-type and S. cerevisiae deletion mutants. CM medium with $2 \%$ glucose minus uracil was used for S. cerevisiae GST-over expressing strains, and $2 \%$ galactose was used to induce the GST-fusion strains. CM broth with glucose and CM broth with glucose minus uracil were purchased from Teknova Inc. (Hollister, CA) (C8000 and C8140 respectively). 


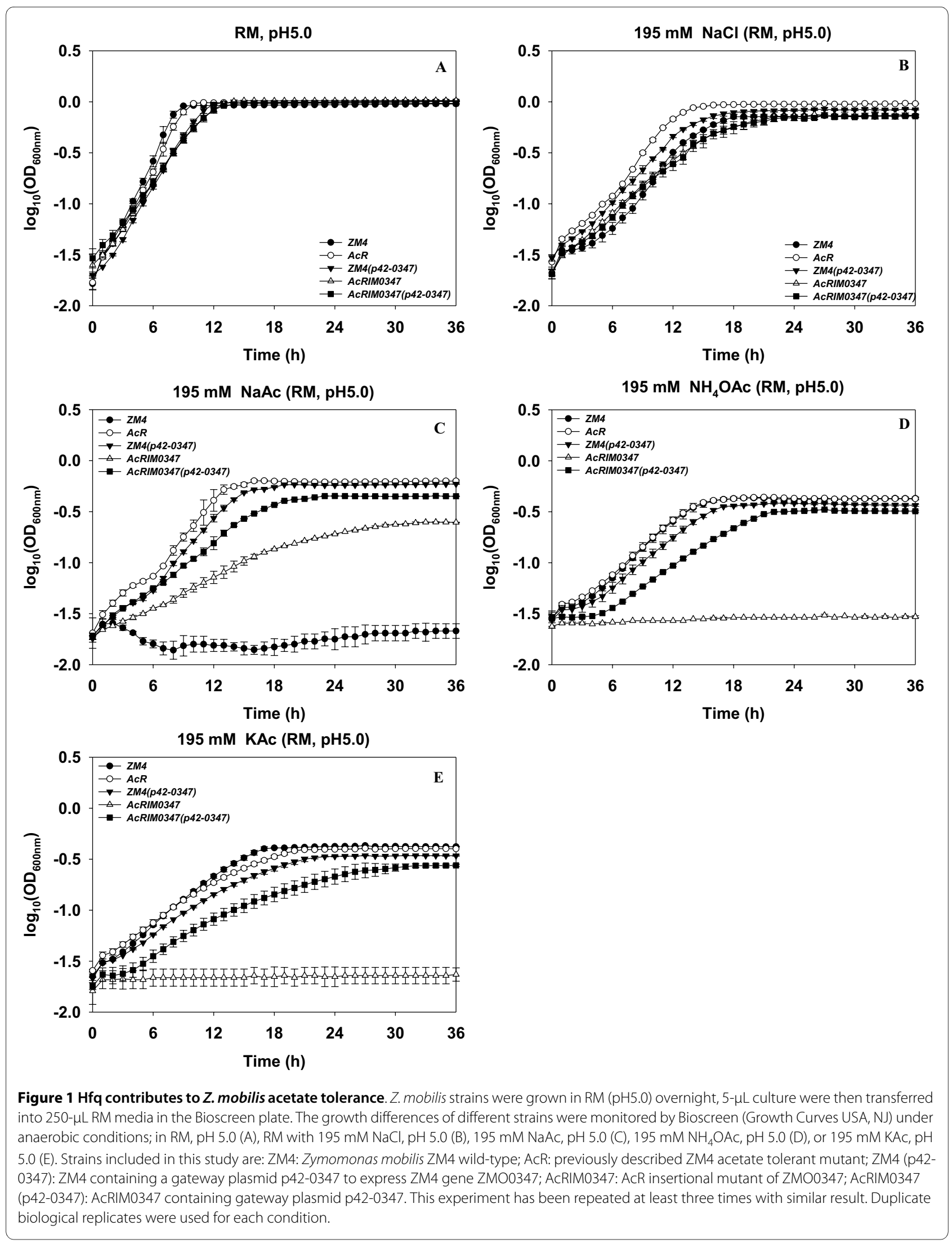




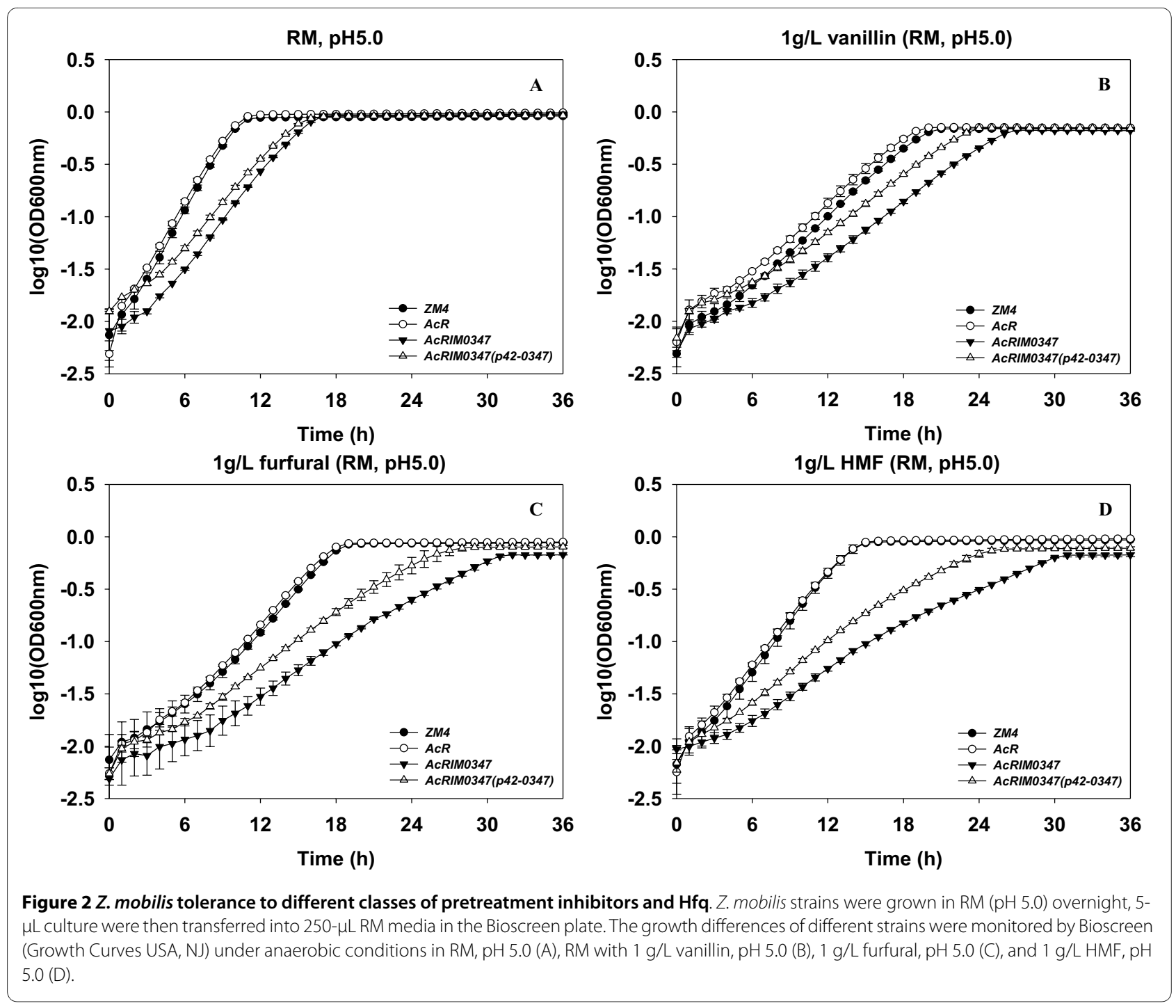

Plasmid-containing strains were routinely grown with antibiotics at the following concentrations $(\mu \mathrm{g} / \mathrm{mL})$ : kanamycin, 50 for E. coli and 200 for ZM4; tetracycline, 10 for E. coli and 20 for ZM4; gentamicin, 10 for E. coli; and G418, 200 for S. cerevisiae YKO deletion mutants. Bacterial growth was monitored using the Bioscreen $\mathrm{C}$ automated microbiology growth curve analysis system using $600_{\mathrm{nm}}$ filter (Growth Curves USA, Piscataway, NJ).

\section{PCR and DNA manipulations}

Genomic DNA from Z. mobilis was isolated using a Wizard Genomic DNA purification kit (Promega, Madison, WI). The QIAprep Spin Miniprep and HiSpeed Plasmid Midi kits (Qiagen, Valencia, CA) were used for plasmid isolation. PCR, restriction enzyme digestion, ligation, cloning, and DNA manipulations were following standard molecular biology approaches as described previously [34] and sequencing was conducted using BigDye Terminator v3.1 cycle sequencing chemistry (Applied
Biosystems Inc, Foster City, CA) on a 48-capillary 3730 DNA Analyzer sequencer (Applied Biosystems Inc).

\section{AcR strain hfq insertional mutant construction}

An $h f q$ insertion mutant was created using the pKnock$\mathrm{Km}$ suicide plasmid system $[26,31]$ in a Z. mobilis acetate tolerant strain (AcR) background and the resulting strain designated as AcRIM0347. Briefly, a 262-bp internal DNA fragment of the Z. mobilis hfq gene (ZMO0347) was amplified by PCR using primers hfq_MF and hfq_MR (Table 1), and ligated into pKnock-Km using Fast-Link ${ }^{\mathrm{m}}$ DNA Ligation Kit (Epicentre). The plasmid was designated as $\mathrm{pKm}-0347$, which was then electroporated into E. coli WM3064. The pKm-0347 plasmid from E. coli WM3064 was verified by PCR and Sanger sequencing analysis. AcR and E. coli WM3064 (pKm-0347) cells were mixed and plated onto RM agar plates with $100 \mu \mathrm{g} / \mathrm{mL}$ DAP and $50 \mu \mathrm{g} / \mathrm{mL}$ kanamycin for conjugation. The cells were incubated at $30^{\circ} \mathrm{C}$ overnight and then subcultured 
on $\mathrm{RM}$ agar plates with $50 \mu \mathrm{g} / \mathrm{mL}$ kanamycin in the absence of DAP. Putative conjugants were then screened by PCR using primers hfq_OCF and hfq_OCR (Table 1). Wild-type AcR has a 1,050-bp PCR product and $h f q$ mutant candidates had a $2.9-\mathrm{kb}$ PCR product. Presumptive positive PCR products from mutant clones were confirmed by Sanger sequencing analysis.

\section{Construction of a Gateway vector for ZMO0347 overexpression and mutant complementation}

Construction of $h f q$ Gateway" entry vector and new destination vector termed pBBR3DEST42 was carried out as previously described [35], except that we used pBBRMCS-3 containing the tetracycline resistance cassette in this study. pBBR3DEST42 was used for $h f q$ expression and the resulting vector designated p42-0347. Briefly, DNA for the target gene was amplified via PCR using AcR genomic template DNA and the hfq_CF and hfq_CR primers (Table 1). PCR products were then cloned into Gateway entry clone pDONR221 using BP Clonase II enzyme mix following the manufacturer's protocol (Invitrogen), transformed into chemically competent DH5 $\alpha$ cells (Invitrogen), and plated onto LB with appropriate antibiotic selection. The identity of insert DNA was confirmed by DNA sequence analysis using the M13 forward and reverse primers (Integrated DNA Technologies, Inc., Coralville, IA). The confirmed entry clone vector was then recombined with destination vector pBBR3DEST42 using LR Clonase II enzyme mix (Invitrogen) to create the expression vector, essentially as described previously [35]. The resulting expression plasmid was designed as p42-0347. The plasmid construct p42-0347 was confirmed by DNA sequence analysis.

ZMO0347 overexpression strain ZM4 (p42-0347) and hfq complemented mutant strain AcRIM0347 (p4202347) were generated by conjugation. Briefly, Z. mobilis (ZM4 or AcRIM0347) cells were mixed with E. coli WM3064 (p42-0347) cells, plated onto RM agar plates with $100 \mu \mathrm{g} / \mathrm{mL}$ DAP and $10 \mu \mathrm{g} / \mathrm{mL}$ tetracycline for conjugation. The cells were incubated at $30^{\circ} \mathrm{C}$ overnight and then subcultured on RM agar plates with $10 \mu \mathrm{g} / \mathrm{mL}$ tetracycline in the absence of DAP. The tetracycline resistant conjugants were confirmed to be correct using PCR and Sanger sequence analysis.

\section{Additional material}

Additional file 1 PPT The comparison of $Z$. mobilis $\mathrm{Hfq}$ protein with homologues from other species. Domain and motif sites of Z. mobilis $\mathrm{Hfa}$ (A), E. coli Hfa (B), S. cerevisiae Sm B (D), and S. cerevisiae Lsm1 (E) proteins based on NCBI BlastP result as well as the alignment for some bacterial $h f a$ homologues (C) using ClustalW 2 http://www.ebi.ac.uk/Tools/clustalw2/ index.html. Residues that are identical across the species are indicated by "*", and residues that are not identical but conserved in function across the species are indicated by ":".
Additional file 2 PPT Map of plasmid vector pBBR3DEST42. The vector map of pBBR3DEST42 plasmid constructed to analyze gene overexpressing and complementation. $\mathrm{Tc}(\mathrm{R})$ : Tetracycline resistance gene tet; $\mathrm{Cm}$ : chloramphenicol resistance gene cat. attR1 and attR2 are recombination sites allowing recombinational cloning of the gene of interest from an entry clone; $c c d B$ is $c c d B$ gene allowing negative selection of expression clones.

Additional file 3 PPT Lsm proteins in S. cerevisiae are involved in multiple inhibitor tolerance. S. cerevisiae strains were grown in CM with $2 \%$ glucose (CM + glucose) for wild-type BY4741 and the deletion mutants, CM with $2 \%$ glucose and $2 \%$ galactose minus uracil (CM + glucose $+2 \%$ galactose) for GST overexpression strains. Five- $\mu \mathrm{L}$ culture was then transferred into 250- $\mu \mathrm{L} \mathrm{CM}$ broth in the Bioscreen plate. The growth differences of different deletion mutant strains were monitored by Bioscreen (Growth Curves USA, NJ) in CM + glucose at pH 5.5 (A), CM + glucose with $305 \mathrm{mM}$ $\mathrm{NaCl}$, pH 5.5 (B), 305 mM NaAc, pH 5.5 (C), $305 \mathrm{mM} \mathrm{NH}_{4} \mathrm{OAc}, \mathrm{pH} 5.5$ (D), and 305 mM KAc, pH 5.5 (E), 0.75 g/L vanillin, pH 5.5 (F), $1.5 \mathrm{~g} / \mathrm{L}$ furfural, pH 5.5 $(\mathrm{G})$, and $1.5 \mathrm{~g} / \mathrm{L} \mathrm{HMF}, \mathrm{pH} 5.5(\mathrm{H})$. The growth differences of different GSTover-expressing strains were monitored by Bioscreen (Growth Curves USA, $\mathrm{NJ}$ ) in CM + glucose $+2 \%$ galactose at pH 5.5 (I), CM + glucose $+2 \%$ galactose with $305 \mathrm{mM} \mathrm{NaCl}$, pH $5.5(\mathrm{~J}), 305 \mathrm{mM} \mathrm{NaAc}$, pH $5.5(\mathrm{~K}), 305 \mathrm{mM}$ $\mathrm{NH}_{4} \mathrm{OAc}$, pH 5.5 (L), 305 mM KAc, pH 5.5 (M), $0.75 \mathrm{~g} / \mathrm{L}$ vanillin, pH 5.5 (N), 1.5 $\mathrm{g} / \mathrm{L}$ furfural, $\mathrm{pH} 5.5(\mathrm{O})$, and $1.5 \mathrm{~g} / \mathrm{L} \mathrm{HMF}, \mathrm{pH} 5.5$ (P). Strains included in this study are listed in table 1 . This experiment has been repeated at least three times with similar result.

\section{Authors' contributions}

SY and SDB designed the experiment, analyzed the data and wrote the manuscript. SY constructed the plasmid pBBR3DEST42 and mutant strains and performed the Bioscreen assays. DAP and TSL constructed the expression vector p42-0347 and carried out the Western-blot. All authors read and approved the final manuscript.

\section{Acknowledgements}

We thank Patricia K. Lankford for Western-blot technical support and the helpful comments from anonymous reviewers for the revision of this manuscript. This work is sponsored by the Laboratory Directed Research and Development Program of Oak Ridge National Laboratory (ORNL), managed by UT-Battelle, LLC for the U. S. Department of Energy under Contract No. DE-AC0500OR22725. The BioEnergy Science Center is a U.S. Department of Energy Bioenergy Research Center supported by the Office of Biological and Environmental Research in the DOE Office of Science.

\section{Author Details}

'Biosciences Division, Oak Ridge National Laboratory, Oak Ridge, TN, 37831, USA and 2BioEnergy Science Center, Oak Ridge National Laboratory, Oak Ridge, TN, 37831, USA

Received: 22 October 2009 Accepted: 7 May 2010

Published: 7 May 2010

\section{References}

1. Almeida JRM, Modig T, Petersson A, Hahn-Hagerdal B, Liden G, GorwaGrauslund MF: Increased tolerance and conversion of inhibitors in lignocellulosic hydrolysates by Saccharomyces cerevisiae. J Chem Tech Biotech 2007, 82(4):340-349.

2. Kadar Z, Maltha SF, Szengyel Z, Reczey K, De Laat W: Ethanol fermentation of various pretreated and hydrolyzed substrates at low initial pH. Appl Biochem Biotechnol 2007, 137:847-858.

3. Takahashi CM, Takahashi DF, Carvalhal MLC, Alterthum F: Effects of acetate on the growth and fermentation performance of Escherichia coli KO11. Appl Biochem Biotechnol 1999, 81(3):193-203.

4. Dien BS, Cotta MA, Jeffries TW: Bacteria engineered for fuel ethanol production: current status. Appl Microbiol Biotechnol 2003, 63(3):258-266.

5. Panesar PS, Marwaha SS, Kennedy JF: Zymomonas mobilis: an alternative ethanol producer. J Chem Technol Biotechnol 2006, 81(4):623-635.

6. Rogers PL, Goodman AE, Heyes RH: Zymomonas ethanol fermentations. Microbiol Sci 1984, 1(6):133-136. 
7. Rogers PL, Jeon YJ, Lee KJ, Lawford HG: Zymomonas mobilis for fuel ethanol and higher value products. Biofuels 2007, 108:263-288.

8. Swings J, De Ley J: The biology of Zymomonas mobilis. Bacterio/ Rev 1977, 41:1-46.

9. Gunasekaran P, Raj KC: Ethanol fermentation technology: Zymomonas mobilis. Curr Sci 1999, 77(1):56-68

10. Ranatunga TD, Jervis J, Helm RF, McMillan JD, Hatzis C: Identification of inhibitory components toxic toward Zymomonas mobilis CP4(pZB5) xylose fermentation. App/Biochem Biotechnol 1997, 67(3):185-198.

11. Lawford HG, Rousseau JD: Improving fermentation performance of recombinant Zymomonas in acetic acid-containing media. Appl Biochem Biotechnol 1998, 70-2:161-172.

12. Lawford HG, Rousseau JD, Tolan JS: Comparative ethanol productivities of different Zymomonas recombinants fermenting oat hull hydrolysate. Appl Biochem Biotechnol 2001, 91-3:133-146.

13. Joachimstahl E, Haggett KD, Jang JH, Rogers PL: A mutant of Zymomonas mobilis ZM4 capable of ethanol production from glucose in the presence of high acetate concentrations. Biotechnol Lett 1998 20(2):137-142.

14. Yang S, Tschaplinski TJ, Engle NL, Carroll SL, Martin SL, Davison BH, Palumbo AV, Rodriguez M Jr, Brown SD: Transcriptomic and metabolomic profiling of Zymomonas mobilis during aerobic and anaerobic fermentations. BMC Genomics 2009, 10(1):34.

15. Tsui HC, Leung HC, Winkler ME: Characterization of broadly pleiotropic phenotypes caused by an hfq insertion mutation in Escherichia coli K12. Mol Microbiol 1994, 13(1):35-49.

16. Sittka A, Lucchini S, Papenfort K, Sharma CM, Rolle K, Binnewies TT, Hinton $J C$, Vogel J: Deep sequencing analysis of small noncoding RNA and mRNA targets of the global post-transcriptional regulator, Hfa. PLOS genetics 2008, 4(8):e1000163.

17. Zhang A, Wassarman KM, Rosenow C, Tjaden BC, Storz G, Gottesman S: Global analysis of small RNA and mRNA targets of Hfq. Mol Microbiol 2003, 50(4):1111-1124.

18. Valentin-Hansen P, Eriksen M, Udesen C: The bacterial Sm-like protein Hfq: a key player in RNA transactions. Mol Microbiol 2004 51(6):1525-1533.

19. Kalnenieks U, Galinina N, Toma MM, Pickford JL, Rutkis R, Poole RK: Respiratory behaviour of a Zymomonas mobilis adhB::kan(r) mutant supports the hypothesis of two alcohol dehydrogenase isoenzymes catalysing opposite reactions. FEBS letters 2006, 580(21):5084-5088.

20. Kalnenieks U, Galinina N, Strazdina I, Kravale Z, Pickford JL, Rutkis R, Poole RK: NADH dehydrogenase deficiency results in low respiration rate and improved aerobic growth of Zymomonas mobilis. Microbiology (Reading, England) 2008, 154(Pt 3):989-994.

21. Kannan R, Mukundan G, Ait-Abdelkader N, Augier-Magro V, Baratti J, Gunasekaran P: Molecular cloning and characterization of the extracellular sucrase gene (sacC) of Zymomonas mobilis. Arch Microbiol 1995, 163(3):195-204.

22. Strzelecki AT, Goodman AE, Rogers PL: Behavior of the IncW plasmid Sa in Zymomonas mobilis. Plasmid 1987, 18(1):46-53.

23. Yang S, Pappas KM, Hauser LJ, Land ML, Chen GL, Hurst GB, Pan C, Kouvelis VN, Typas MA, Pelletier DA, et al:: Improved genome annotation for Zymomonas mobilis. Nat Biotechnol 2009, 27(10):893-894.

24. Taylor MP, Esteban CD, Leak DJ: Development of a versatile shuttle vector for gene expression in Geobacillus spp. Plasmid 2008, 60(1):45-52

25. Walia SK, Carey VC, All BP, Ingram LO: Self-transmissible plasmid in Zymomonas mobilis carrying antibiotic resistance. Appl Environ Microbiol 1984, 47(1):198-200

26. Alexeyev MF: The pKNOCK series of broad-host-range mobilizable suicide vectors for gene knockout and targeted DNA insertion into the chromosome of gram-negative bacteria. BioTechniques 1999, 26(5):824-826. 828

27. Nielsen JS, Boggild A, Andersen CBF, Nielsen G, Boysen A, Brodersen DE, Valentin-Hansen P: An Hfq-like protein in archaea: Crystal structure and functional characterization of the Sm protein from Methanococcus jannaschii. RNA 2007, 13(12):2213-2223.

28. Cherry JM, Adler C, Ball C, Chervitz SA, Dwight SS, Hester ET, Jia Y, Juvik G, Roe T, Schroeder M, et al:: SGD: Saccharomyces Genome Database. Nucleic Acids Res 1998, 26(1):73-79

29. Weng S, Dong Q, Balakrishnan R, Christie K, Costanzo M, Dolinski K, Dwight SS, Engel S, Fisk DG, Hong E, et al.: Saccharomyces Genome
Database (SGD) provides biochemical and structural information for budding yeast proteins. Nucleic Acids Res 2003, 31(1):216-218.

30. Altschul SF, Gish W, Miller W, Myers EW, Lipman DJ: Basic local alignment search tool. J Mol Biol 1990, 215(3):403-410

31. Brown SD, Martin M, Deshpande S, Seal S, Huang K, Alm E, Yang Y, Wu L, Yan T, Liu X, et al:: Cellular response of Shewanella oneidensis to strontium stress. Appl Environ Microbiol 2006, 72(1):890-900.

32. Yang S, Land ML, Klingeman DM, Pelletier DA, Lu TS, Martin SL, Guo HB, Smith JC, Brown SD: A paradigm for industrial strain improvement identifies sodium acetate tolerance mechanisms in Zymomonas mobilis and Saccharomyces cerevisiae. Proc Natl Acad Sci USA in press.

33. Joachimsthal EL, Rogers PL: Characterization of a high-productivity recombinant strain of Zymomonas mobilis for ethanol production from glucose/xylose mixtures. App/ Biochem Biotechnol 2000, 84-86:343-356.

34. Sambrook JaRD: Molecular Cloning: A Laboratory Manual (Third Edition). Cold Spring Harbor Laboratory Press; 2000.

35. Pelletier DA, Hurst GB, Foote LJ, Lankford PK, McKeown CK, Lu TY, Schmoyer DD, Shah MB, Hervey WJ, McDonald WH, et al:: A general system for studying protein-protein interactions in gram-negative bacteria. J Proteome Res 2008, 7(8):3319-3328.

36. Kovach ME, Elzer PH, Hill DS, Robertson GT, Farris MA, Roop RM, Peterson KM: Four new derivatives of the broad-host-range cloning vector pBBR1MCS, carrying different antibiotic-resistance cassettes. Gene 1995, 166(1):175-176.

doi: 10.1186/1471-2180-10-135

Cite this article as: Yang et al., The Zymomonas mobilis regulator hfa contributes to tolerance against multiple lignocellulosic pretreatment inhibitors BMC Microbiology 2010, 10:135

\section{Submit your next manuscript to BioMed Central and take full advantage of:}

- Convenient online submission

- Thorough peer review

- No space constraints or color figure charges

- Immediate publication on acceptance

- Inclusion in PubMed, CAS, Scopus and Google Scholar

- Research which is freely available for redistribution
C BioMed Central 